\title{
The Impact of Prostate Needle Biopsy on Erectile Function
}

\author{
Prostat Iğne Biyopsisinin Erektil Fonksiyon Üzerine Etkisi
}

\author{
(1) Fatih Yanaral, (1) Faruk Özgör, (1) Metin Savun, (1) Ali Ayrancı, (1) Ufuk Çağlar, (1) Alkan Çubuk, (1) Ömer Sarılar \\ University of Health Sciences, Haseki Training and Research Hospital, Department of Urology, istanbul, Turkey
}

\section{Abstract}

Aim: To evaluate the impact of transrectal ultrasonography-guided prostate needle biopsy (PNB) on erectile function.

Methods: Patients who underwent PNB were prospectively examined. The indications for prostate biopsy were elevated or increasing PSA and/or abnormal digital rectal examination. All patients were evaluated with the 5-item version of the International Index of Erectile Function (IIEF-5) before PNB and at 1, 3 and 6 months after PNB. Severity of erectile dysfunction (ED) was classified into five categories according to IIEF-5 scores.

Results: Eighty patients were included in the study. The mean age of patients was 64.7 and the mean serum PSA level was $10.2 \mathrm{ng} / \mathrm{ml}$. The mean IIEF-5 score was 16.5 prior to PNB. Before PNB, ED was reported in 61 patients and mild, mild to moderate, and moderate ED in 23 (28.8\%), 21 (26.2\%), and 17 (21.2\%) patients, respectively. Six months after PNB, ED was reported as mild, mild to moderate, moderate and severe in 23 (28.8\%), 21 (26.3\%), 16 (20\%) and 1 (1.3\%) patients, respectively. The differences are statistically insignificant $(p>0.05)$.

Conclusion: TNB does not have a permanent effect on erectile function. It seemed to be a trend toward increasing ED at 1 month and longer follow-up showed that these changes resolved back to baseline.

Keywords: Biopsy, erectile dysfunction, prostate, prostate cancer

\section{Öz}

Amaç: Transrektal ultrasonografi eşliğinde prostat iğne biyopsisinin (PiB) erektil fonksiyon üzerine etkisini değerlendirmek.

Yöntemler: РіB yapılan hastalar prospektif olarak incelendi. Prostat biyopsisi endikasyonları; yüksek veya artan PSA ve/veya anormal parmakla rektal muayene idi. Tüm hastalar PiB öncesinde ve PiB sonrası birinci, üçüncü ve altıncı aylarda Uluslararası Erektil Fonksiyon Indeksinin (IIEF-5) 5 maddelik versiyonu ile değerlendirildi. Erektil disfonksiyon (ED) şiddeti, IIEF-5 skorlarına göre beş kategoriye ayrıldı.

Bulgular: Seksen hasta çalışmaya dahil edildi. Hastaların ortalama yaşı 64.7 ve ortalama serum PSA düzeyi $10.2 \mathrm{ng} / \mathrm{ml}$ idi. Ortalama IIEF-5 skoru PiB öncesi 16.5 idi. PiB öncesi 61 hastada ED vardı ve hafif, hafiforta ve orta derece ED'li hasta sayısı sırasıyla 23 (\%28,8), $21(\% 26,2)$ ve 17 (\%21.2) idi. PiB'dan altı ay sonra ED, sırasıyla 23 (\%28,8), 21 $(\% 26,3), 16(\% 20)$ ve $1(\% 1,3)$ hastada hafif, hafif-orta, orta ve şiddetli olarak rapor edildi. Bu farklar istatistiksel olarak anlamsızdı ( $p>0,05)$.

Sonuç: TiB'nin erektil işlev üzerinde kalıı bir etkisi yoktur. Birinci ayda ED'nin artması yönünde bir eğilim olsada, uzun dönem takipte bu değişikliklerin işlem öncesi değerlere geri dönmektedir.

Anahtar Sözcükler: Biyopsi, prostat, prostat kanser, setleşme bozukluğu

\section{Introduction}

Prostate cancer is the second most commonly diagnosed cancer among males and around 1.1 million diagnoses worldwide in 2012 constitute $15 \%$ of all diagnosed cancers (1). Transrectal ultrasonography-guided prostate needle biopsy (PNB) is the gold standard diagnostic procedure to confirm the presence of cancer in men with abnormal serum prostate specific antigen (PSA) and/or digital rectal examination (DRE). It is estimated that over 2 million PNB are carried out in the United States and Europe every year $(2,3)$.
Address for Correspondence/Yazışma Adresi: Fatih Yanara

University of Health Sciences, Haseki Training and Research Hospital, Department of Urology, İstanbul, Turkey

Phone: +90 5055866142 E-mail: fatihyanaral@gmail.com

Received/Geliş Tarihi: 19 January 2018 Accepted/Kabul Tarihi: 10 March 2018
${ }^{\circ}$ Copyright 2018 by The Medical Bulletin of University of Health Sciences Haseki Training and Research Hospital
The Medical Bulletin of Haseki published by Galenos Yayınevi.

OTelif Hakkı 2018 Sağlık Bilimleri Üniversitesi Haseki Eğitim ve Araştırma Hastanesi Haseki Tıp Bülteni, Galenos Yayınevi tarafından basıımıştır. 
Prostate biopsy is well tolerated especially when combined with local anesthesia and the risk of major complications is low. Minor complications, such as hematuria, hematospermia, and rectal bleeding are more common but are usually self-limited. Furthermore, infection and urinary retention are less common. Data on quality of life, and erectile and voiding function following PNB are inadequate and heterogeneous with respect to patient populations and erectile dysfunction (ED) classifications $(2,4)$. Several authors reported that transient voiding impairment might be precipitated by prostate biopsy $(5,6)$. It is known that the likelihood of cancer leads to anxiety on the patient, which may be related to ED (7).

In this prospective study, we aimed to evaluate the impact of transrectal ultrasonography-guided prostate needle biopsy on erectile function.

\section{Methods}

Patients who underwent PNB between January 2015 and January 2016 were prospectively examined. Patients with previous prostate biopsy history, pre-biopsy severe $E D$, no sexual intercourse during the study period, and the pathologic diagnosis of prostate cancer were excluded from the study. The indications for prostate biopsy were elevated or increasing PSA (>2.5 ng/ml) and/or abnormal DRE (stiffness, nodule). Systemic diseases associated with ED (diabetes mellitus, hypertension) were recorded.

Ciprofloxacin 500 mg (twice a day) was started day before the procedure. To achieve anesthesia, $10 \mathrm{ml}$ of $2 \%$ lidocaine was instilled in the rectum 10 minutes before the procedure started. We used a probe reinforced with a transrectal ultrasound with an automated spring biopsy gun and a disposable 18-gauge $20 \mathrm{~cm}$ biopsy needle. We performed sextant biopsy (at least 6 cores each lobe) with additional cores from suspect areas. Prostate volume was calculated using the ellipsoid formula (Volume $=$ length $\times$ height $\times$ width $\times 0.53$ ). Patients with diagnosed prostate cancer were not included in the study and therapeutic options were offered depending on age, comorbidity, and tumor stage.

All patients were prospectively evaluated with the 5-item version of the International Index of Erectile Function (IIEF-5) before PNB and at 1, 3 and 6 months after PNB. We classified ED severity into five categories according to IIEF-5 scores; severe (5-7), moderate (8-11), mild to moderate (12-16), mild (17-21), and no ED (22-25). None of the patients has received treatment (5-phosphodiesterase inhibitors, prostaglandin) to improve sexual function.

\section{Statistical Analysis}

The Statistical Package of Social Sciences for Windows version 20 was used for statistical analysis. The IIEF-5 scores were compared with the use of the paired t test. Statistical significance was considered when two-tailed $p$ value $<0.05$.

\section{Results}

Eighty patients without prostate cancer were included in the study. The mean age of patients was $64.7 \pm 7.1$ and the mean serum PSA level was $10.2 \pm 7.6 \mathrm{ng} / \mathrm{ml}$ (Table 1). Of the patients 19 (23.7\%) had abnormal DRE findings. Prior to PNB 45 patients (56.2\%) had concomitant EDrelated systemic diseases (diabetes mellitus, hypertension). The mean prostate volume of patients was $56.4 \pm 33.7$ (Table 1). There was no serious complication in any case during the procedure.

\begin{tabular}{|l|l|}
\hline \multicolumn{2}{|l|}{ Table 1. Characteristics of the study population } \\
\hline Age $^{*}$ (years) & $64.7 \pm 7.1$ \\
\hline BMI* $^{*}\left(\mathbf{g g} / \mathbf{m}^{2}\right)$ & $27.4 \pm 4.8$ \\
\hline Abnormal DRE (\%) & $19(23.7)$ \\
\hline Serum PSA* (ng/ml) & $10.2 \pm 7.6$ \\
\hline Concomitant ED related disease (\%) & $45(56.2)$ \\
\hline Prostate Volume ${ }^{*}(\mathbf{m L})$ & $56.4 \pm 33.7$ \\
\hline Prior IIEF-5 Score* & $16.5 \pm 5.3$ \\
\hline $\begin{array}{l}\text { BMl: Body mass index, DRE: Digital rectal examination, PSA: Prostate specific } \\
\text { antigen, ED: Erectile dysfunction, IIEF: International Index of Erectile Function } \\
{ }^{*} \text { Mean } \pm \text { standart derivation }\end{array}$ \\
\hline
\end{tabular}

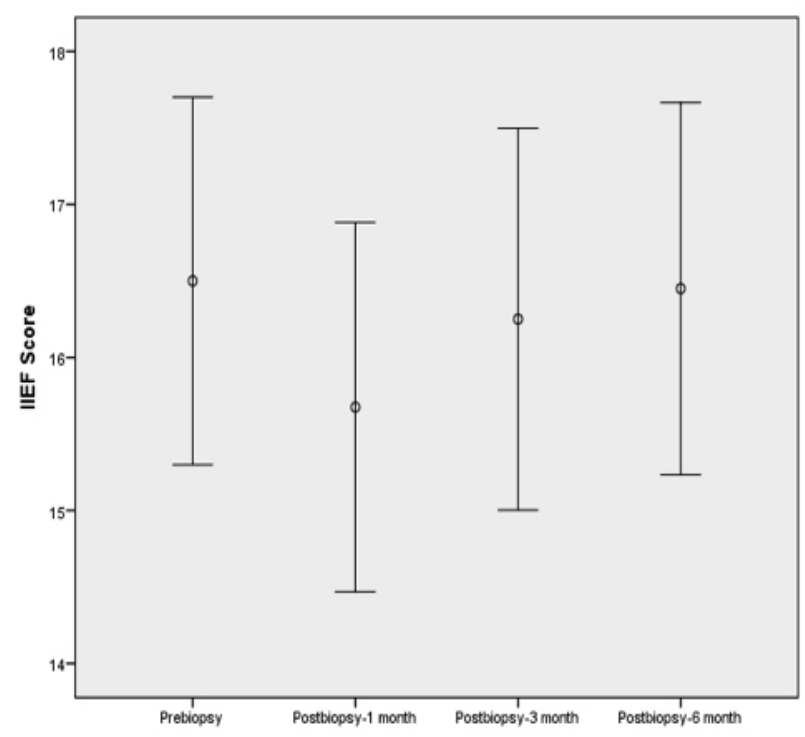

Figure 1. IIEF-5 scores during follow up period IIEF: International Index of Erectile Function 


\begin{tabular}{|c|c|c|c|c|c|c|c|}
\hline IIEF-5 Score & Prebiopsy & 1 month after biopsy & $p^{*}$ value & $\begin{array}{l}3 \text { months after } \\
\text { biopsy }\end{array}$ & $\mathrm{p}^{*}$ value & $\begin{array}{l}6 \text { months } \\
\text { after biopsy }\end{array}$ & $\mathbf{p}^{*}$ value \\
\hline $\begin{array}{l}\text { Absence of ED } \\
(22-25)\end{array}$ & $19(23.8 \%)$ & $16(20 \%)$ & 0.10 & $18(22.5 \%)$ & 0.33 & $19(23.8 \%)$ & 0.32 \\
\hline $\begin{array}{l}\text { Mild ED } \\
(17-21)\end{array}$ & $23(28.8 \%)$ & $23(28.8 \%)$ & 0.18 & $23(28.8 \%)$ & 0.32 & $23(28.8 \%)$ & 0.32 \\
\hline $\begin{array}{l}\text { Mild to Moderate ED } \\
(12-16)\end{array}$ & $21(26.3 \%)$ & $19(23.8 \%)$ & 0.06 & $20(25 \%)$ & 0.36 & $21(26.3 \%)$ & 0.32 \\
\hline $\begin{array}{l}\text { Moderate ED } \\
(8-11)\end{array}$ & $17(21.3 \%)$ & $18(22.5 \%)$ & 0.08 & $17(21.3 \%)$ & 0.16 & $16(20 \%)$ & 0.33 \\
\hline $\begin{array}{l}\text { Severe ED } \\
(5-7)\end{array}$ & 0 & $4(5 \%)$ & 0 & $2(2.5 \%)$ & 0 & $1(1.3 \%)$ & 0 \\
\hline
\end{tabular}

The mean IIEF-5 score was $16.5 \pm 5$ prior to PNB (Table 1). Before PNB, ED was reported in 61 patients (76.2\%) and mild, mild to moderate, and moderate ED in 23 (28.8\%), $21(26.2 \%)$, and $17(21.2 \%)$ patients, respectively. No patients reported severe ED in the study group before PNB. ED was reported as mild, mild to moderate, moderate and severe in 23 (28.8\%), 19 (23.8\%), 18 (22.5\%) and $4(5 \%)$ patients, respectively after one month and 23 (28.8\%), $21(26.3 \%), 16(20 \%)$ and 1 (1.3\%) patients, respectively after six months (Table 2, Figure 1). As shown in Table 2, the differences are statistically insignificant $(p>0.05)$ in terms of general and partial values.

\section{Discussion}

Transrectal ultrasonography-guided prostate needle biopsy is one of the most common urological procedures in the world (2). Men undergoing prostate biopsy expect to experience the same quality of life, including sexual performance following procedure. ED is a highly prevalent, age-related progressive medical problem that negatively affects the quality of life (8). There has been significant controversy as to whether PNB predisposes patients to ED. In some publications, prostate biopsy causes shortterm exacerbation of urinary symptoms and leads to anxiety and transient ED (9). The IIEF is the most widely used self-report instrument for the evaluation of male sexual function (10). The IIEF-5 questionnaire includes five items of the IIEF-15, while the final item addresses sexual intercourse satisfaction. In this study, we used the Turkish form of IIEF-5 validated by Turunc et al in 2007 (11). Our study has one of the longest follow-up durations in the current literature with 6 months follow up period to evaluate long-term impact of PNB.
The diagnosis of prostate cancer has an impact on many aspects of a man's life and may even increase stressrelated events. According to the prospective study of 85 patients by Helfand et al., they found a relationship between prostate cancer and ED. On multivariate analysis they reported that prostate cancer diagnosis was significantly associated with a decrease in IIEF score ( $p=$ $0.001)(12)$. Therefore, in our study patients diagnosed with prostate cancer were excluded from the study. Thus, the possibility of prostate cancer that affects the outcome of the study has been disabled.

Zisman et al. evaluated 211 patients and reported that preoperative anxiety was seen in $64 \%$ of patients and it's a predictive factor of intraoperative pain. Anxiety peaked before the result of pathology. The psychological concern of patients waiting for a biopsy result may lead to ED. ED attributed to anxiety in anticipation of biopsy was reported in $7 \%$ of cases. At days 7 and $30,15 \%$ of previously potent patients reported ED (13). For this reason, the evaluation of IIEF scores should be performed before PNB to accurately define the patient's erectile function before prostate cancer diagnosis and treatment.

Repeated biopsies may be performed on men with clinical suspicion of abnormal serum PSA or digital rectal examination to prostate cancer. With the increasing acceptance of active surveillance as a viable option for some patients with low risk prostate cancer, more men are undergoing serial PNB. In 2009, Fujita et al. analyzed 231 patients with prostate cancer on an active surveillance protocol and followed for a mean of 3.2 years. According to their results, significant correlations were found between the number of biopsies and worsening ED, with an increasing number of biopsies being associated 
with a decrease in the SHIM (Sexual Health Inventory for Men) scores. They concluded that serial prostate biopsies, especially three or more, appear to have an adverse effect on erectile function in men with prostate cancer on active surveillance (14). During active surveillance, the data on ED from multiple PNB are more difficult. All of these men have prostate cancer and that aging during the years between biopsies may have independently led to worsening ED. Consequently, in the present study patients who had a history of previous biopsy were excluded and only patients who had undergone first biopsy were included.

Saturation biopsies with 20 or more cores are used to evaluate patients with previously negative biopsies who are clinically suspected to have prostate cancer. Akbal et al. analyzed 74 prostate cancer-free patients following transrectal ultrasound guided saturation biopsy. The new onset mild ED rate was $11.6 \%$ at 1 month, and that subsequently resolved after 6 months (15). Similar to our findings, this study suggests that a single PNB is not associated with ED.

The precise etiology of erectile problems following prostate biopsy is unknown. It is possible that direct anatomical damage to the neurovascular bundle or hematoma/edema caused by nerve compression may lead to ED (13). Transient inflammatory and neurovascular damage may cause by periprostatic nerve block. (PPNB). PPNB provides superior analgesia during PNB. Most protocols involve the use of lidocaine that is infiltrated into the junction between the seminal vesicles and the base of the prostate, where the neurovascular bundles are anatomically positioned. In a prospective study, Klein et al. evaluated the effect of PNB and a periprostatic nerve block on erectile function. Seventy-one patients were randomized to 10-core PNB with PPNB and 74 were randomized to undergo 10-core PNB with lidocaine gel only. They concluded that erectile function is transiently impaired after prostate biopsy regardless of PPNB and impairment is reversible within 3 months (16).

In 2006, Chrisofos et al. examined 46 men after PNB, and new onset ED was reported in $6.5 \%$ and $4.3 \%$ of patients at 1 and 3 months, respectively. They found no significant difference in erectile function in the 1st month and 3rd month after PNB (7). In our study, the ED rate after biopsy increased compared to the before biopsy, however the difference was not significant (prebiopsy: $76.2 \%$ vs 1 month after: $80 \%, p>0.05$ ). Additionally, ED incidence did not change at 6 months from biopsy (prebiopsy: $76.2 \%$ vs after six months: $76.2 \%, p>0.05)$. Only $1(1.3 \%)$ patient complained about severe ED at 6-month evaluation, who had moderate ED before biopsy.

This study has some limitations. First relatively small sample size. Second, the clinical impact of number of cores, and prostate size on our results were not evaluated. Lastly, the patients' anxiety levels were not assessed.

\section{Conclusion}

Present study showed that transrectal ultrasonographyguided prostate needle biopsy does not have a permanent effect on erectile function. It seemed to be a trend toward increasing ED at 1 month and longer follow-up showed that these changes resolved back to baseline. Therefore, before prostate biopsy potent patients should be informed about the temporary detriment in erectile function.

\section{References}

1. Ferlay J, Soerjomataram I, Dikshit R, et al. Cancer incidence and mortality worldwide: sources, methods and major patterns in GLOBOCAN 2012. Int J Cancer 2015;136:E35986.

2. Loeb S, Vellekoop A, Ahmed HU, et al. Systematic review of complications of prostate biopsy. Eur Urol 2013;64:876-92.

3. Loeb S, Carter HB, Berndt SI, Ricker W, Schaeffer EM. Complications after prostate biopsy: data from SEERMedicare. J Urol 2011;186:1830-4.

4. Rosario DJ, Lane JA, Metcalfe C, et al. Short term outcomes of prostate biopsy in men tested for cancer by prostate specific antigen: prospective evaluation within ProtecT study. BMJ 2012;344:d7894.

5. Zisman A, Leibovici D, Kleinmann J, Cooper A, Siegel $Y$, Lindner A. The impact of prostate biopsy on patient wellbeing: a prospective study of voiding impairment. J Urol 2001;166:2242-6.

6. Bozlu M, Ulusoy E, Doruk E, et al. Voiding impairment after prostate biopsy: does tamsulosin treatment before biopsydecrease this morbidity?. Urology 2003;62:1050-3.

7. Chrisofos M, Papatsoris AG, Dellis A, Varkarakis IM, Skolarikos A, Deliveliotis C. Can prostate biopsies affect erectile function?. Andrologia 2006;38:79-83.

8. Feldman HA, Goldstein I, Hatzichristou DG, Krane RJ, McKinlay JB. Impotence and its medical and psychosocial correlates: results of the Massachusetts Male Aging Study. J Urol 1994;151:54-61.

9. Glaser AP, Novakovic K, Helfand BT. The impact of prostate biopsy on urinary symptoms, erectile function, and anxiety. Curr Urol Rep 2012;13:447-54.

10. Rhoden EL, Telöken C, Sogari PR, Vargas Souto CA. The use of the simplified International Index of Erectile Function (IIEF5 ) as a diagnostic tool to study the prevalence of erectile dysfunction. Int J Impot Res 2002;14:245-50.

11. Turunç T, Deveci S, Güvel S, Peşkircioğlu, L. The assessment of Turkish validation with 5 question version of International Index of Erectile Function (IIEF-5). Türk Üroloji Dergisi 2007;33:45-9.

12. Helfand BT, Glaser AP, Rimar K, et al. Prostate cancer diagnosis is associated with an increased risk of erectile dysfunctionafter prostate biopsy. BJU Int 2013;111:38-43. 
13. Zisman A, Leibovici $D$, Kleinmann J, Siegel $Y$ I, Lindner A. The impact of prostate biopsy on patient well-being: a prospective study of pain, anxiety and erectile dysfunction. J Urol 2001;165:445-54.

14. Fujita K, Landis P, McNeil BK, Pavlovich CP. Serial prostate biopsies are associated with an increased risk of erectile dysfunction in men with prostate cancer on active surveillance. J Urol 2009;182:2664-9.
15. Akbal C, Türker P, Tavukçu HH, Simşek F, Türkeri L. Erectile function in prostate cancer-free patients who underwent prostate saturationbiopsy. Eur Urol 2008;53:540-4.

16. Klein T, Palisaar RJ, Holz A, Brock M, Noldus J, Hinkel A. The impact of prostate biopsy and periprostatic nerve block on erectile and voidingfunction: a prospective study. J Urol 2010;184:1447-52. 